\title{
PENDEKATAN DESAIN SISTEM SOSIAL-TEKNIS UNTUK MENDUKUNG KOMPETENSI LULUSAN DI JAWA BARAT
}

\section{SOCIAL-TECHNICAL SYSTEM DESIGN APPROACH TO SUPPORT GRADUATES COMPETENCY IN WEST JAVA}

\author{
Iyan Gustiana ${ }^{1}$, Novrini Hasti ${ }^{2}$, Wahyuni $^{3}$, D D Sanjoyo ${ }^{4}, \mathrm{~S}$ R Mubaroq ${ }^{5}$ \\ ${ }_{1,2,3}$ Departemen Sistem Informasi, Fakultas Teknik dan Ilmu Komputer, \\ Universitas Komputer Indonesia, Bandung, Indonesia, \\ ${ }^{4}$ Universitas Telekomunikasi, Bandung, Indonesia \\ ${ }^{5}$ Universitas Pendidikan Indonesia, Bandung, Indonesia \\ iyan.gustiana@email.unikom.ac.id
}

\begin{abstract}
Abstrak
Tujuan dari penelitian ini adalah merancang sistem sosial-teknis sebagai solusi untuk mengatasi pengangguran terbuka di Jawa Barat, yaitu lulusan sarjana. Peningkatan jumlah pengangguran terbuka tingkat universitas (lulusan TI) cenderung meningkat setiap tahun. Salah satu alasannya adalah bahwa kompetensi lulusan tidak sesuai dengan yang dibutuhkan oleh bisnis dan industri. Maka, perlu untuk membuat desain yang bisa mengatasi hal ini. Penelitian ini menggunakan metode analisis Triple Helix dan sistem sosial-teknis. Langkah analitik yang diambil dalam penelitian ini adalah observasi dokumenter dan pengolahan data statistik. Hasil penelitian ini diusulkan desain teknis dan desain implementasi sebagai bentuk kolaborasi dari universitas dan industri yang dibantu oleh pemerintah sebagai regulator. Desain ini dapat digunakan oleh universitas, untuk meningkatkan kurikulum dan penelitian. Harapan dari desain ini dapat memperbarui dan meningkatkan kebutuhan bisnis dan industri dan memiliki lulusan yang kompeten.
\end{abstract}

\section{Kata Kunci : Sosial-teknis, Pengangguran, Lulusan sarjana}

\begin{abstract}
The purpose of this study is to design a social-technical system as a solution to overcome open unemployment in West Java, namely undergraduate graduates. The increase in the number of university-level open unemployment (IT graduates) tends to increase every year. One reason is that graduate competencies do not match what is needed by business and industry. Then, it is necessary to create a design that can overcome this. This research used the Triple Helix analysis method and the social-technical system. The analytical step taken in this research is documentary observation and statistical data processing. The results of this
\end{abstract}


study are proposed technical design and implementation design as a form of collaboration from universities and industry, which is assisted by the government as a regulator. This design can be used by universities to improve curriculum and research. Expectations of this design can renew and enhance business and industrial needs and have competent graduates.

\section{Keyword: Social-technical, Unemployment, Undergraduate graduates}

\section{PENDAHULUAN}

Pendahuluan menguraikan tentang latar Open Unemployment Rate (OUR) adalah indikator yang dapat digunakan untuk mengukur tingkat pasokan tenaga kerja yang tidak digunakan atau tidak diserap oleh pasar tenaga kerja [1]. Tingkat pengangguran terbuka di provinsi Jawa Barat cenderung meningkat setiap tahun [1]. Untuk Agustus 2019 ada angka $7,99 \%$, ini bisa dilihat dari hasil survei Biro Statistik Jawa Barat pada Agustus 2019. Untuk tahun berjalan, ada penurunan $0,18 \%$ dari tahun sebelumnya, seperti yang ditunjukkan pada Gambar 1. Total tenaga kerja pada tahun 2019 adalah 23,80 juta yang terdiri dari 21,90 orang yang bekerja dan 1,90 juta yang menganggur. Jumlah 21,90 juta orang yang pekerjaannya dibagi menjadi $49,82 \%$ bekerja di sektor formal dan $50,18 \%$ bekerja di sektor informal. Pendidikan tinggi menyumbang tenaga kerja 2,52 juta orang atau $10,59 \%$. Banyak hal yang menyebabkan pengangguran di Jawa Barat, selain persaingan dengan sesama pencari kerja [2], salah satu yang mendasar adalah tingkat kompetensi lulusan yang tidak memadai mengikuti kebutuhan bisnis dan industri. Kompetensi terkait erat dengan kualitas pengajaran dari dosen, dan kualitas pengajaran juga tergantung pada kurikulum yang dirancang [3].

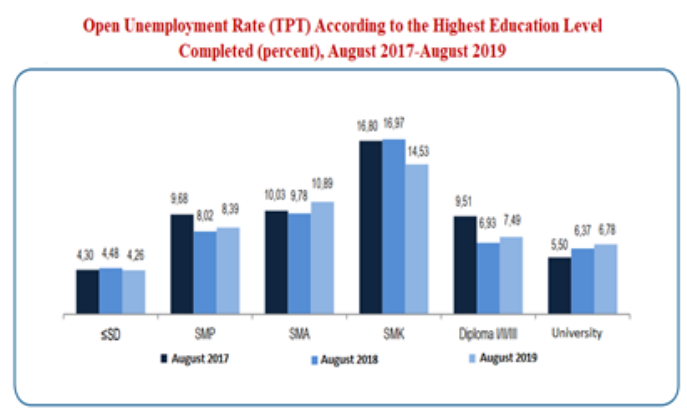

Gambar 1. Data Pengangguran di Jawa Barat (sumber data BPS)

Desain kurikulum yang terjadi sejauh ini biasanya setiap 4 tahun. Jika dibandingkan dengan tingkat bisnis dan industri, kebutuhan belum relevan. Ada harapan, lulusan bisa langsung bekerja. Namun pada kenyataannya, mayoritas lulusan universitas belum memenuhi persyaratan untuk bekerja, seperti lulusan TI. Karena itu, akan baik bagi universitas untuk bekerja dengan bisnis dan industri, dan sebaliknya, dapat berbagi tentang kebutuhan dan kompetensi yang dibutuhkan oleh 
dunia bisnis saat ini. Mereka dapat berbagi peran, universitas melakukan penelitian, sementara bisnis dan industri mengimplementasikan hasil penelitian dari universitas. Jika ini diterapkan, itu bisa memiliki dampak luar biasa, terutama untuk pertumbuhan ekonomi di masyarakat [4]. Banyak yang bisa dilakukan untuk melibatkan dunia bisnis dan industri di kampus, melalui penciptaan kurikulum bersama, seperti Jepang untuk membuat kurikulum permainan [5]. Bisa juga dalam penelitian bersama, seperti tetangga kita Malaysia, bisa berkolaborasi dengan universitas dan industri di bidang penelitian [6]. Dengan demikian, hasil kolaborasi dapat dibandingkan dengan perusahaan yang mengadakan kolaborasi yang bisa jauh lebih unggul dari perusahaan yang tidak memiliki hubungan dengan kampus. Kolaborasi ini kemudian dapat melibatkan organisasi induk. Untuk perguruan tinggi berbasis komputer, misalnya, ada Asosiasi Pendidikan Tinggi Ilmu Komputer (APTIKOM) yang memiliki cabang di setiap provinsi dan telah ditunjuk oleh pemerintah untuk mempromosikan penerapan pendidikan terbuka di Indonesia. APTIKOM telah memperkenalkan Kerangka Kerja Arsitektur Pendidikan Terbuka dan telah bekerja sama dengan kantor Wakil Presiden Indonesia dan Kementerian Pendidikan dan Kebudayaan, fasilitas ini dapat digunakan oleh universitas [7].

Penelitian ini adalah desain teknis yang diusulkan dan desain implementasi yang akan digunakan oleh universitas. Desain teknis dikembangkan menggunakan model kolaborasi Triple Helix. Model ini akan mengusulkan berbagai skenario inisiasi dan kolaborasi antara universitas dan industri. Karena itu dari skenario ini, dapat diwujudkan dalam perencanaan yang matang dan menjadi peta jalan untuk periode tertentu. Pada bagian hasil dan diskusi, bentuk perencanaan kolaboratif antara universitas dan industri akan dijelaskan dalam bentuk desain teknis yang diusulkan dalam pembuatan kurikulum dan penelitian serta implementasinya sehingga hasil kolaborasi dapat berjalan dengan lancar dan mengurangi bentrokan pihak-pihak yang terlibat. Kemudian, itu termasuk elemen non-teknis seperti sosial dan psikologi dengan desain sistem sosial-teknis. Kesimpulan dari penelitian ini adalah membuat desain teknis dan proposal desain implementasi untuk menghasilkan lulusan TI yang kompeten sehingga mereka dapat memenuhi kebutuhan bisnis dan industri. 


\section{METODE PENELITIAN}

Untuk mengatasi masalah pengangguran terbuka di Jawa Barat, khususnya lulusan TI, diperlukan alat untuk mengurai masalah. Alat yang digunakan untuk menemukan aktor dan pada saat yang sama dapat menemukan solusi, kita membutuhkan model, yaitu Triple Helix. Sementara itu, untuk menjaga integritas kolaborasi, dapat bertahan lama dan menjadi budaya, alat yang tepat adalah Sistem Desain Sosial-teknis (DSTS).

\section{Triple Helix Model}

Model Triple Helix diciptakan oleh Leydesdorff dan Etzkowitz (2001), untuk menghubungkan universitas sebagai produsen pengetahuan dengan pengguna pengetahuan (industri), dan pemerintah sebagai regulator. Sejauh ini, sebagian besar hasil penelitian universitas hanya dipamerkan di pameran dan konten publikasi, bukan pada tahap produksi massal, yang menghasilkan manfaat ekonomi. Untuk produksi massal dibatasi oleh peraturan. Demikian juga, ketika pengusaha dan industri ingin membuat penemuan, mereka harus menemukan ahli mereka sendiri, membuat laboratorium sendiri dan meneliti sendiri. Oleh karena itu, perlu ada pendekatan dari kedua belah pihak yang difasilitasi oleh pemerintah $[8,9]$
Gambar 2 menjelaskan model triple helix tentang bagaimana universitas, industri, dan pemerintah dengan domain yang berbeda (dibedakan berdasarkan warna) dapat memainkan fungsi masing-masing tetapi masih berkolaborasi secara sinergis [10]. Komitmen dan sinergi dari pihakpihak yang terlibat diharapkan menghasilkan sumber daya manusia yang kompeten dan dapat berkontribusi langsung pada pengembangan teknologi di industri dan dapat diterapkan di masyarakat. Model Triple Helix memiliki tiga kondisi dasar sebagai berikut:

1. Universitas sebagai inovasi teknologi memiliki level yang sama dengan industri dan pemerintah.

2. Negara harus mendorong setiap kelompok akademik, bisnis, dan pemerintah untuk memainkan peran yang lebih aktif sehingga dapat memperluas potensi inovasi diri.

3. Universitas (Akademik), bisnis (industri), dan pemerintah bekerja sama untuk memunculkan proses kebijakan inovasi daya saing ekonomi [11]. 


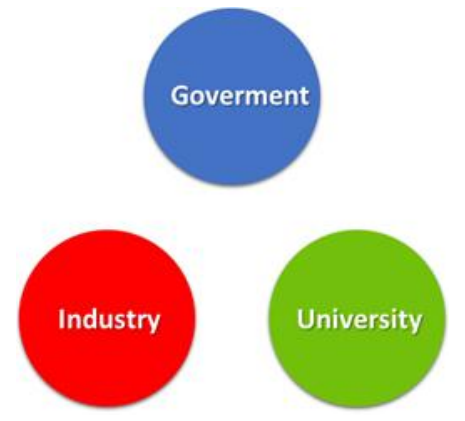

Gambar 2. Model Triple Helix

\section{Socio-Technical System Design (STSD)}

The Social-Technical System Design Method (STSD) adalah pendekatan dalam mendesain dengan pertimbangan manusia, sosial dan organisasi, serta faktor teknis dalam desain sistem organisasi. Menerapkan pendekatan ini adalah pemahaman yang lebih baik tentang bagaimana faktor-faktor yang disebutkan di atas mempengaruhi cara kerja dilakukan dan berkontribusi [12]. Proses desain sistem informasi menggunakan desain sistem sosioteknik terkait dengan partisipasi pengguna termasuk saran. Sistem ini mencakup jaringan pengguna, pengembang, teknologi informasi, desain desain interaksi manusia-komputer dan lingkungan di mana sistem akan didukung dan digunakan [13]. Pendekatan SDST sangat baik tetapi orang jarang menggunakannya karena kompleksitas dalam menggunakan dan hubungan metode ini dengan masalah teknis dan interaksi antara individu dan sistem [14].
Terdapat kecenderungan bagi universitas untuk fokus pada studi dan penelitian untuk menemukan jawaban atas masalah, sementara industri menggunakan metode lain. Jika universitas dan industri ingin saling terbuka dengan berkolaborasi dalam penelitian, inovasi dalam industri akan diperoleh [15]. Karena itu, hasil inovasi dapat dikembangkan dan memenuhi unsur pemberdayaan bisnis dan ekonomi. Kolaborasi ini juga akan mempengaruhi kompetensi lulusan universitas sehingga energinya dapat terserap sebanyak mungkin untuk kebutuhan industri. Universitas dan sektor industri masih timpang, dan mereka tidak bersinergi. Karena kurangnya sinergi, lulusan perguruan tinggi yang merupakan kebutuhan sektor industri tidak sejajar dengan output tenaga kerja atau penelitian universitas. Akibatnya, pengusaha tetap menganggap hasil riset atau produk lulusan perguruan tinggi belum siap digunakan. Sehingga kolaborasi antara universitas dan industri terus ditingkatkan dalam berbagi dana dan memanfaatkan hasil penelitian untuk tujuan bisnis.

\section{Helix Triple Alternatif yang Diusulkan}

Dengan melihat komplikasi di atas, model Triple Helix perlu 
dibuat. Alternatif pertama adalah merancang Model Triple Helix, di mana pemerintah menjadi regulator murni, tidak berpartisipasi dalam kolaborasi langsung, yang dapat dilihat pada Gambar 3 di bawah ini. Gambar 3 adalah model Triple Helix yang diusulkan, di mana pemerintah bertindak sebagai regulator, tidak berinteraksi langsung dengan industri atau domain universitas. Bentuk kolaborasi antara industri dan universitas dapat mencakup penelitian, pengembangan kurikulum, beasiswa, pembuatan lab. dll. Model alternatif Triple Helix berikutnya adalah bahwa pemerintah tidak hanya regulator tetapi juga berperan aktif dalam kolaborasi sesuai dengan fungsi masing-masing domain. Setiap domain dapat dievaluasi, diisi, dan dibahas satu sama lain sehingga proses penciptaan sumber daya manusia (sarjana) yang berkualitas dapat segera dibuat.

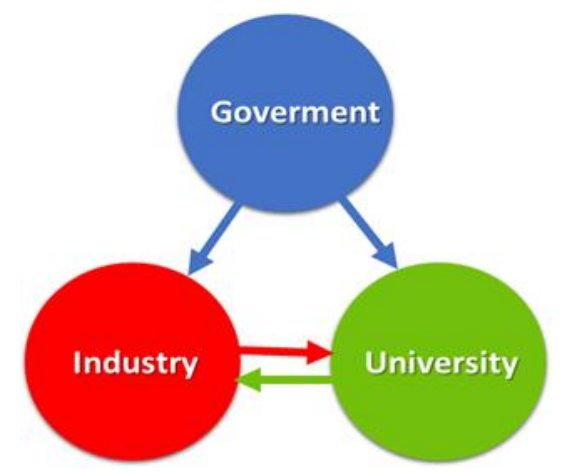

Gambar 3. Triple Helix Model

(Pemerintah sebagai regulator)

Gambar 4 adalah model Triple Helix terintegrasi yang cakupannya lebih luas dan melibatkan banyak pihak, yaitu pemerintah, perusahaan, dan universitas [9]. Setiap domain berfungsi dengan fungsi dan perannya. Pemerintah sebagai regulator, juga mendengar masukan dari industri dan universitas untuk membuat kebijakan yang mendukung kolaborasi dan bahkan memfasilitasi infrastruktur dan fasilitas [16].

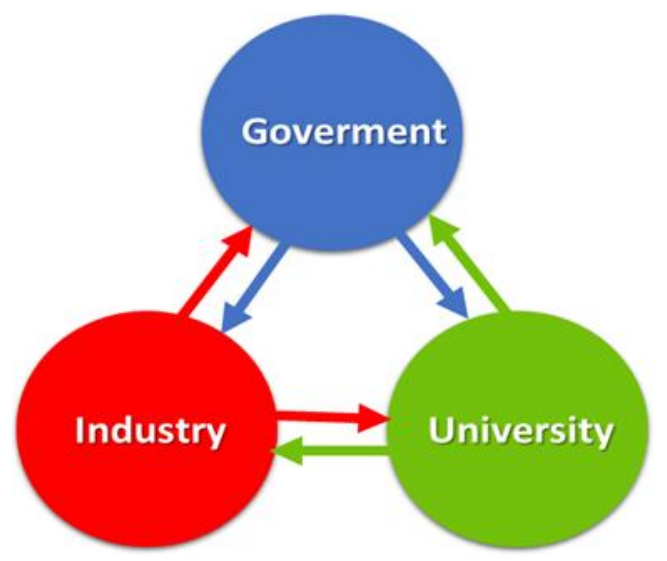

Gambar 4. Triple Helix Model (Collaboration across domains)

\section{Ide Model Bisnis Diusulkan untuk Kolaborasi Universitas dan Industri}

Gagasan kolaborasi antara universitas dan industri dengan berfokus pada perubahan kurikulum dan penelitian didasarkan pada analisis data statistik tentang jumlah pengangguran terbuka dan kenyataan pengamatan tidak langsung saat melakukan bimbingan mahasiswa tesis. 
Kemudian model bisnisnya adalah sebagai berikut Gambar 5.

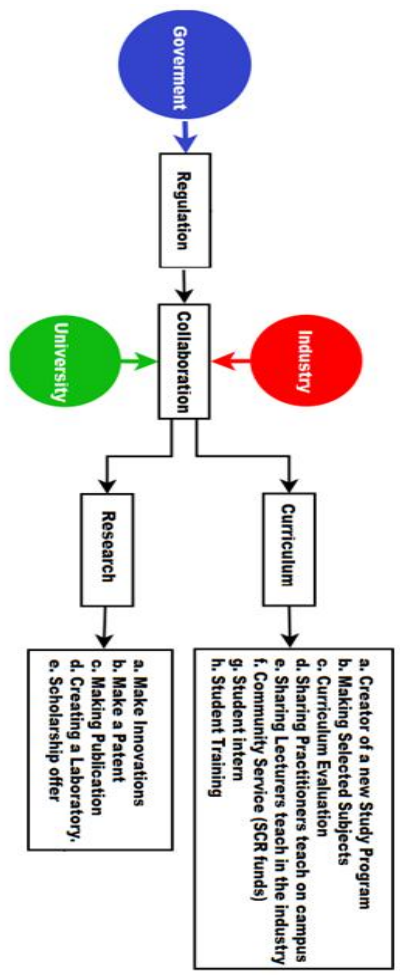

Gambar 5. Ide Model Bisnis yang

Diajukan untuk Kolaborasi

Universitas dan Industri

Gagasan model bisnis ini, di masa depan, peta jalan, kelompok kerja, SOP, dan penjelasan masing-masing pekerjaan dapat dibuat. Jika Anda berkomitmen pada pihak-pihak yang terlibat, cetak biru dapat dibuat, untuk dapat bergulir perlahan dan pasti, desain menggunakan desain sistem sosial-teknis (DSST). Desain sosioteknis digunakan karena desain ini dapat menggambarkan orang, sosial dan organisasi, dan budaya. Model desain sistem sosio-teknis dapat mengelola domain yang disebutkan oleh Triple Helix dengan berbagai mekanisme. Kolaborasi Triple Helix sangat cocok untuk karakteristik DSTS yang dikenal sebagai penelitian tindakan partisipatif [17]. SDST dapat digunakan untuk berkontribusi dalam memecahkan masalah ini dalam situasi kerja dengan syarat bahwa semua pihak bersedia untuk mendengarkan dan setuju untuk bekerja sama dalam mengembangkan strategi [18]. Oleh karena itu, keberhasilan SDST ini dalam pengembangan atau desain SI akan bekerja dengan baik jika kondisi terpenuhi yaitu interaksi sosial, partisipasi, dan komunikasi yang lancar dapat membuat keputusan kolektif. Persyaratan selanjutnya adalah kejelasan urutan sehingga mudah untuk pengambilan keputusan. Kondisi terakhir adalah keberadaan mediator sebagai media dari pihakpihak yang berkolaborasi sehingga proses partisipatif dapat dikelola dengan baik. Jika semua kondisi di atas dilakukan dengan benar, proses kolaborasi model Triple Helix dengan proses bisnisnya akan berjalan seperti yang diharapkan [19]. Lalu, akan ada beragam studi dan inovasi yang memiliki efek strategis pada evaluasi kurikulum dan lulusan juga akan memiliki kompetensi yang relevan dengan tuntutan dunia kerja. 


\section{KESIMPULAN}

Berdasarkan hasil pembahasan di atas, untuk membantu mengatasi Open Unemployment Rate (OUR) khususnya lulusan IT dan untuk memiliki kompetensi yang dibutuhkan oleh bisnis dan industri, perlu untuk membuat proposal desain teknis dan desain implementasi yang melibatkan pihak terkait ke model Triple Helix untuk berkolaborasi sesuai dengan tugas dan fungsinya masing-masing. Kolaborasi antara universitas dan industri berfokus pada peningkatan dan peningkatan kurikulum dan penelitian karena ini adalah salah satu dasar untuk membentuk lulusan yang kompeten. Diharapkan kolaborasi ini dapat diwujudkan dalam bentuk peta jalan bersama, sehingga tujuan dan sasarannya jelas. Desain implementasi menggunakan desain sistem sosioteknis sehingga dapat berjalan dengan lancar dan mengurangi bentrokan dalam komunikasi dengan pihak-pihak yang berkolaborasi. Sehingga menciptakan lulusan yang kompeten yang sesuai dengan kebutuhan bisnis dan industri.

\section{DAFTAR PUSTAKA}

[1] Badan Pusat Statistik and P. J. Barat, Keadaan Ketenagakerjaan Provinsi Jawa Barat Agustus 2019, (62), pp. 1-12, 2019.
[2] R. R. Sekar, A. Dian, A. Nina, and L. Seniati, "The Influence of Trait Competitiveness on Job Search Intensity among Job Seekers of Generation Y," 1994.

[3] A. P. Prasetio, E. Azis, D. D. Fadhilah, and A. F. Fauziah, 'Lecturers' Professional Competency and Students' Academic Performance in Indonesia Higher Education," Int. J. Hum. Resour. Stud., 7(1), pp. 8693, 2017, DOI: 10.5296/ijhrs.v7i1.10902, 2017.

[4] J. Guan and Q. Zhao, "The impact of universityindustry collaboration networks on innovation in nanobiopharmaceuticals, "

Technol. Forecast. Soc. Change, 80(7), pp. 12711286 , DOI: 10.1016/j.techfore.2012.11. 013, 2013.

[5] K. Mikami et al., "Construction trial of a practical education curriculum for game development by industry-university collaboration in Japan, Comput. Graph”., 34(6), pp. 791-799, 2010, DOI: 10.1016/j.cag.2010.09.015, 2010. 
[6] M. S. Salleh and M. Z. Omar, "University-industry

Collaboration Models in Malaysia," Procedia - Soc. Behav. Sci., vol. 102, no. Ifee 2012, pp. 654-664, , DOI: 10.1016/j.sbspro.2013.10.784, 2013.

[7] A. Open, E. Architectural, E. Dazki, and R. E. Indrajit, "Aptikom Open Education Architectural Framework A Strategic Platform to Implement Online Learning in Higher Education Environment," Indones. J. Netw. Secur., 5(2), pp. 7-10, 2016.

[8] F. Urem, E. Ban, and D. Jurekovic, "Enhancing digital competences of Croatian teachers of informatics Oracle academy use case," 2018 41st Int. Conv. Inf. Commun. Technol. Electron. Microelectron. MIPRO 2018 Proc., no. February 2019, pp. 605-609,

DOI: 10.23919/MIPRO.2018.840011 4, 2018.

[9] L. Leydesdorff, "Triple Helix of University-Industry-

Government Relations,"

Encycl. Creat. Invent. Innov. Entrep., pp. 1-9, DOI: 10.1007/978-1-4614-66161_452-2, 2017.
[10] J. Lee and H. N. Win, "Technology transfer between university research centers and industry in Singapore," Technovation, 24(5), pp. 433-442, 2004, DOI: $\quad 10.1016 / \mathrm{S} 0166-$ 4972(02)00101-3, 2004.

[11] D. Schartinger, C. Rammer, and J. Fröhlich, "Knowledge interactions between universities and industry in Austria: Sectoral patterns and determinants," Innov. Networks, Knowl. Spillovers Sel. Essays, 31, pp. 135-166, DOI: 10.1007/3-540-35981-8_7, 2006.

[12] G. Baxter and I. Sommerville, "Socio-technical systems: From design methods to systems engineering," Interact. Comput., 23(1), pp. 4-17, 2011.

[13] W. Scacchi, "Socio-Technical System Design," Berksh. Encycl. Human-Computer Interact., no. September 2003, pp. 1-10, 2004.

[14] T. S. Eicher et al., "Sociotechnical Systems: A Metadesign Perspective." 2011.

[15] I. M. Bodas Freitas, R. A. Marques, and E. M. D. P. E. Silva, "University-industry collaboration and innovation in emergent and 
mature industries in new industrialized countries," Res. Policy, 42(2), pp. 443-453, DOI:

10.1016/j.respol.2012.06.006, 2013.

[16] L. Martini, J. H. Tjakraatmadja, Y. Anggoro, A. Pritasari, and L. Hutapea, "Triple Helix Collaboration to Develop Economic Corridors as Knowledge Hub in Indonesia," Procedia - Soc. Behav. Sci., 52, pp. 130-139, DOI: 10.1016/j.sbspro.2012.09.449, 2012.

[17] A. G. Sutcliffe and S. Minocha, "Linking business modelling to socio-technical system design," Lect. Notes Comput. Sci. (including Subser. Lect. Notes Artif. Intell. Lect. Notes Bioinformatics),1626, pp. 7387, DOI: $10.1007 / 3-540-$ 48738-7_7, 1999.

[18] H. Hariyanto and M. Anwar, "Socio-technical Approach to Agricultural Information Systems Development," 227, no. Icamr 2018, pp. 469-474, DOI: $\quad 10.2991 /$ icamr18.2019.113, 2019.

[19] Henry Etzkowitz and Chunyan Zhou, "The Triple Helix, Second Edi. London \& New York: Routledge", Tailor \& Francis Group, 2018. 